\title{
Assessment of Stability for Seed Cotton Yield of Cotton Genotypes Across Different Environmental Conditions of Sindh Province
}

\author{
Zaheer Ahmed Deho*, Saifullah Abro and Muhammad Rizwan
}

Nuclear Institute of Agriculture (NIA), Tando Jam, Pakistan.

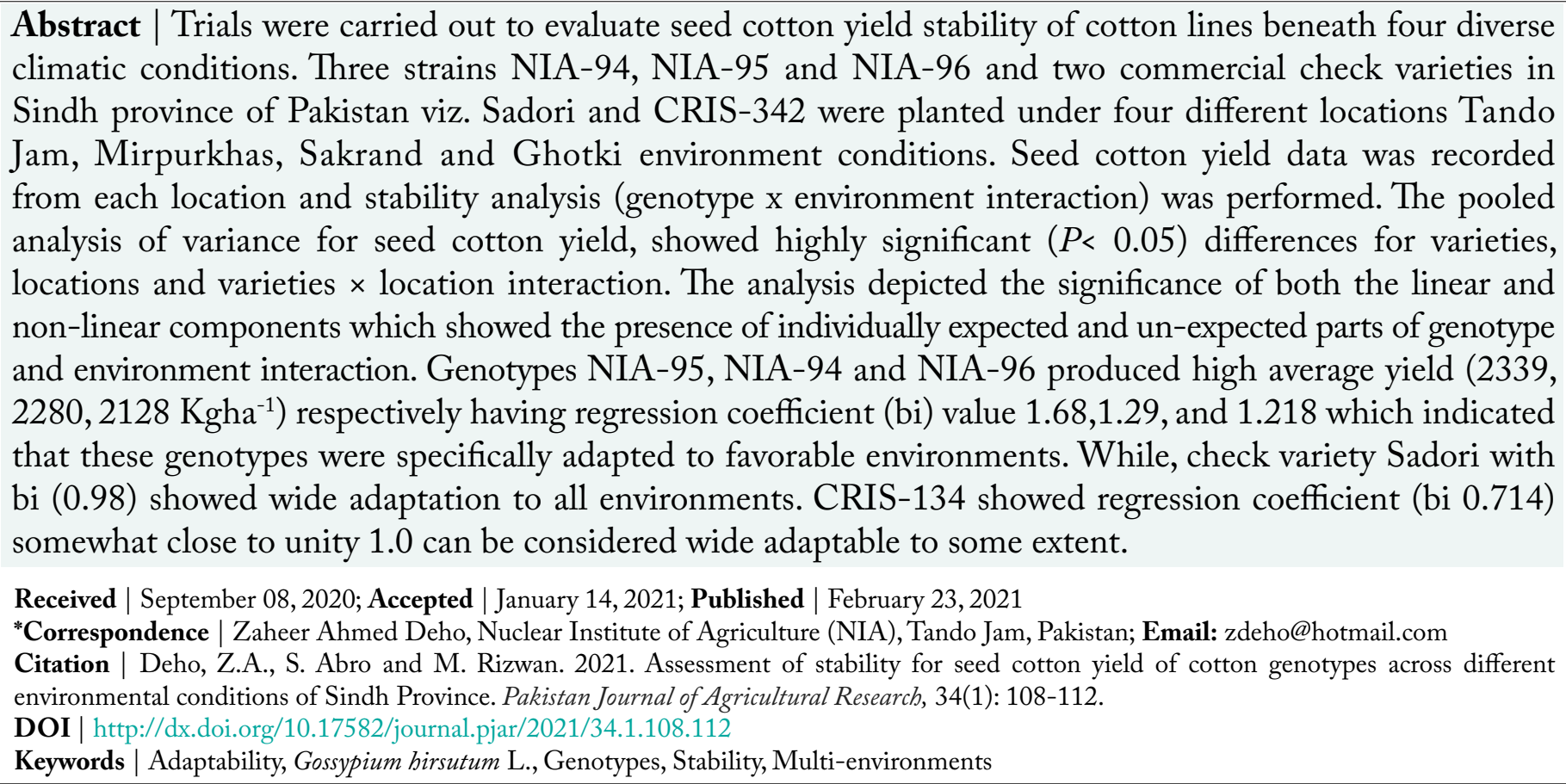

\section{Introduction}

$\mathrm{C}$ otton is developed in tropical and sub-tropical agro-ecological zones. Rapidly changing and unpredictable climatic conditions demand to identify and introduce more stable cotton genotypes with specific adaptation to specific environments (Iqbal et al.,2018).It is essential to evaluate adaptation and yield stability of promising genotypes across environments. The yield potential of a genotype is the outcome of its interface with the presented environment. The strong effects of ecological factors throughout different phases of crop development, hence genotypes vary broadly in their response to climate (Sial et al., 2000; Bull et al., 1992). Study was carried out with a view to find out the effect of $\mathrm{G} \times \mathrm{E}$ interaction on the yields of new cotton genotypes to identify the firmest and modified genotypes. Sustainable yield requires stable cultivars. Plant breeding is essential phase to recognize firm and extra adjustable strains/genotypes. The learning of stability in cotton is indispensable component of plant breeding earlier to the launch of latest crop variety, generally difference of sites and years are important for sufficient estimates regarding genotypes.

Cotton production requires identification and crop growing of firm cultivars. Genotypes $\times$ environment $(\mathrm{G} \times \mathrm{E})$ interactions are of main concern to plant breeders for rising better and stable strains (Tuteja et 
al., 2006). Assessment the constancy and flexibility of genotypes transversely diverse atmosphere situation is essential for initiate and advice of latest crop variety which assurance their elevated flexibility. Plant breeders assess germplasm at various locations in different trials to find out the adaptability of genotypes and to propose the cultivars to dissimilar locations (Maleia et al., 2017).

The principle of the work is to estimate the performance of the developed genotypes for stability in cotton yield over dissimilar climatic conditions. Keeping in view the above facts, this research was conducted for evaluating the potential of developed lines for stability and profitable crop growing across different locations in Sindh province.

\section{Materials and Methods}

Multi-location trials of cotton strains were carried out during two consecutive years 2018 and 2019.The experiments were conducted at 04 different locations (TandoJam, Mirpurkhas, Sakrand and Ghotki) in Sindh, Pakistan. Five cotton genotypes. Three advanced lines namely; NIA-94, NIA-95 and NIA96 and two were standard cultivars Sadori and CRIS342. The experiments were conducted in randomized complete block design with three replicates. The size of the plot measured was $15^{\prime}$ x 20 ' sq. ft, comprising of eight rows $75 \mathrm{~cm}$ distance apart for each entry. The cultural practices were done as and when required. The data collected and analyzed separately for each location and subjected to analysis of variance following (Steel et al., 1997). The values presented are mean of three replicates \pm standard error (SE). Stability analysis of genotypes was completed for yield data from replication trials at multi-environments. Analysis comprised of site wise analysis of variance (ANOVA) and the combined analysis of variance for any place/ environment (Pooled ANOVA). Stability traits were figured out by following the stability model given by (Eberhart and Russell, 1966).

\section{Results and Discussion}

Stability study helps in perceptive the adaptability of genotypes over diverse ecological conditions and the recognition of adjustable genotypes. (Dewdar, 2013). Combined ANOVA for seed cotton yield (Table 1) revealed highly significant variation with the genotypes, environments and genotype $\times$ environment
$(\mathrm{G} \times \mathrm{E})$ interaction. Highly significant difference among genotypes might be due to distinction in their inherited frame and varied natural history of beginning. The highly significant differences in sites indicated the presence of variation in the current environment. The highly significant interaction among genotypes and environments may be either a cross over or a noncross over nature. The pooled analysis revealed the significance of both the linear and non-linear (pooled deviation) components which indicated the presence of both foreseeable and un-foreseeable components of genotypes and environments interaction (Table 2). Farias et al. (2016) evaluated cotton strains in dissimilar locations. This study showed that some varieties had superior performance over a single environment and little performance in others, which shows change in their average performance over multi-environments and revealed significant $\mathrm{G} \times \mathrm{E}$ interaction. Similar trends were observed by (Riaz et al., 2013; Maleia et al., 2010; Moiana et al., 2014; de Carvalho et al., 2015; Pretorius et al., 2015) who evaluated cotton cultivars in various environmental experiments in Pakistan, Mozambique, South Africa and Brazil. Performance of genotypes at various sites is presented in (Table 3). The highest site mean yield was recorded at CRS, Ghotki $\left(2303 \mathrm{Kgha}^{-1}\right)$ followed by NIA, Tando Jam (2172 Kgha $\left.{ }^{-1}\right)$.The results reflected that these sites had favorable environment for higher yield. The lowest yields were obtained at CRI, Sakrand (2089 Kg ha ${ }^{-1}$ ) and CRS, Mirpur Khas $\left(2045 \mathrm{Kgha}^{-1}\right)$ respectively depicting that these sites had unfavorable environments for higher seed cotton yield. Mean yield of genotype NIA-95 in general performed better (2339 $\mathrm{Kgha}^{-1}$ ) than the other genotypes across all four locations while NIA-96 as poorest genotype $\left(2128 \mathrm{Kgha}^{-1}\right)$. The results achieved in this study satisfied one of the breeder's goals for selecting stable genotypes with acceptable seed cotton yield over a range of environments. The stability parameters calculated for yield of cotton genotypes are presented in Table 4. Among the genotypes, NIA95, NIA-94 and NIA-96 produced high average yield $\left(2339,2280,2128 \mathrm{Kgha}^{-1}\right)$ respectively and whereas these genotypes have regression values higher than 1.0 possesses specific adaptation to favorable or high yielding environments and deviation from regression line $\left(\mathrm{S}^{2} \mathrm{~d} \sim 0\right)$ was close to unity ' 0 'indicated that these genotypes possess general stability. These results are in accordance with the findings of some previous studies (Killi and Harem, 2006; Khan et al., 2007; Naveed et al., 2006; Riaz et al., 2013) which reported 
Table 1: Combined analysis of variance for seed cotton yield $\left(\mathrm{kgha}^{-1}\right)$ of cotton genotypes tested over different environments.

$\begin{array}{lll}\text { Sources } & \begin{array}{l}\text { Degree of free- } \\ \text { dom (d.f) }\end{array} & \begin{array}{l}\text { Mean square } \\ (\mathbf{m . s})\end{array} \\ \text { Years } & 1 & 377217^{* *} \\ \text { Locations } & 3 & 384067^{* *} \\ \text { Genotypes } & 4 & 597583^{* *} \\ \text { Year } \times \text { Location } & 3 & 403775^{* *} \\ \text { Year } \times \text { Location× Genotype } & 12 & 73325^{* *} \\ \text { Error } & 78 & 11459 \\ \text { Total } & 119 & \\ \text { *,**, ns; significant at 5\%, 1\% probability levels and non-significant, } \\ \text { respectively }\end{array}$

Table 2: Pooled analysis of variance.

$\begin{array}{llll}\text { Sources } & \text { DF } & \text { MS } & \text { F-value } \\ \text { Total } & 19 & 35387.789 & \\ \text { Environments (Env.) } & 3 & 64008.000 & \\ \text { Varieties (Var.) } & 4 & 99594.000^{* *} & 40.268 \\ \text { Var. } \times \text { Env. } & 12 & 6830.667 & \\ \text { Env. + Var. × Env. } & 15 & 18266.133 & \\ \text { Env. (Lin.) } & 1 & 192027.984 & \\ \text { Var. } \times \text { Env. (Lin) } & 4 & 14307.871^{* *} & 5.785 \\ \text { Pooled Dev. } & 10 & 2473.253 & 0.216 \\ \text { Pooled Error } & 64 & 11459.390 & \end{array}$

F-test: Deviation from Regression: Pooled Dev. MS / Pooled Error $M S$, Var. $x$ Env. $($ Lin $)=$ Var. $x$ Env. (Lin) $M S /$ Pooled Dev.MS: Varieties $=$ Varieties $/$ Pooled Dev.MS .

Table 3: Seed cotton yield $\left(\mathrm{Kgha}^{-1}\right)$ of cotton genotypes tested different locations over two years during kharif (2018 and 2019).

$\begin{array}{lllllll}\text { Locations } & \text { NIA- } & \text { NIA- } & \text { NIA- } & \text { Sadori } & \text { CRIS- Site } \\ & \mathbf{9 4} & \mathbf{9 5} & \mathbf{9 6} & & \mathbf{3 2 4} & \text { mean } \\ \text { NIA, Tando } & 2225 & 2368 & 2117 & 2278 & 2189 & 2172 \mathrm{~b} \\ \text { Jam } & \mathrm{c}-\mathrm{f} & \mathrm{bc} & \mathrm{c}-\mathrm{g} & \mathrm{b}-\mathrm{e} & \mathrm{c}-\mathrm{f} & \\ \text { CRS, Mir- } & 2067 & 2150 & 1975 & 1930 & 1969 & 2045 \mathrm{c} \\ \text { pur Khas } & \mathrm{c}-\mathrm{g} & \mathrm{c}-\mathrm{g} & \mathrm{d}-\mathrm{g} & \mathrm{e}-\mathrm{g} & \mathrm{d}-\mathrm{g} & \\ \text { CCRI, } & 2195 \mathrm{c}- & 2183 & 2047 & 1960 & 1913 & 2089 \mathrm{c} \\ \text { Sakrand } & \mathrm{f} & \mathrm{c}-\mathrm{f} & \mathrm{c}-\mathrm{g} & \mathrm{d}-\mathrm{g} & \mathrm{fg} & \\ \text { CRS, } & 2832 \mathrm{a} & 2958 \mathrm{a} & 2627 & 1947 & 2237 & 2303 \mathrm{a} \\ \text { Ghotki } & & & \mathrm{ab} & \mathrm{d}-\mathrm{g} & \mathrm{c}-\mathrm{f} & \\ \text { Genotypic } & 2280 \mathrm{a} & 2339 \mathrm{a} & 2128 \mathrm{~b} & 1955 \mathrm{c} & 2059 \mathrm{~b} & \\ \text { mean } & & & & & & \end{array}$

the stability and $\mathrm{G} \times \mathrm{E}$ interaction in genotypes of cotton and the effect of distinct environments on seed cotton yield to understand their adaptation to different environments. The lines NIA-95, NIA-
94 and NIA-96 produced high average yield (2339, 2280 and $2128 \mathrm{kgha}^{-1}$, respectively having regression coefficient (bi) value $1.68,1.29$ and 1.218 which indicated that these genotypes were especially adapted to favorable environments. While check variety Sadori with bi (0.98) showed wide adaptation to all types environments. CRIS-134 showed regression coefficient (bi 0.714 ) somewhat close to unity 1.0 can be considered as wide adaptable to some extent. Every year a huge number of newly developed genotypes are being assessed for their yield stability and suitability for particular environmental conditions. This is the pre-requisite activity to approve and recommend the new cotton varieties for general cultivation in the country (Iqbal et al., 2018).

Table 4: Stability parameters for seed cotton yield (Kgha 1) genotypes tested under different environments over two years.

$\begin{array}{llll}\text { Source } & \begin{array}{l}\text { Over all mean } \\ \text { seed yield } \\ \left.\text { (Kgha }^{-1}\right)\end{array} & \begin{array}{l}\text { Regression } \\ \text { coefficient } \\ (\mathbf{b i})\end{array} & \begin{array}{l}\text { Deviation from } \\ \text { regression coeffi- } \\ \text { cient }\left(\mathbf{S}^{2} \mathbf{d}\right)\end{array} \\ \text { NIA-94 } & 2280 \mathrm{a} & 1.29 & 0.005 \\ \text { NIA-95 } & 2339 \mathrm{a} & 1.68 & 0.000 \\ \text { NIA-96 } & 2128 \mathrm{~b} & 1.218 & 0.001 \\ \text { Sadori } & 1955 \mathrm{c} & 0.98 & 0.005 \\ \text { CRIS-324 } & 2059 \mathrm{~b} & 0.714 & 0.002\end{array}$

\section{Conclusions and Recommendations}

From present study it is concluded that the genotypes Sadori and CRIS-134 with low regression coefficient and deviation from regression coefficient are wide adaptable to the range of environments. While the cotton genotypes NIA-94, NIA-95 and NIA96 showed highest regression coefficient values, which suggest their specific adaptation to favorable environments.

\section{Novelty Statement}

Cotton is considered as a life line of economy of Pakistan. There is lot of studies on stability analysis. The stability assessments of advance cotton genotypes across the different environmental conditions of Sindh province are rare. Further the germplasm used in present study are novel and never included in such kind of studies before. 
Author's Contribution

ZAD developed basic ideas, experiment/theoretical setting, preparation of writing research paper. SA helped in the execution of experiment. MR contributed in data analysis and technical assistance regarding manuscript review.

\section{Conflict of interest}

The authors have declared no conflict of interest.

\section{References}

Bull, J.K., M. Cooper, I.H. Delacy, K.E. Basford and D.R. Woodruff. 1992. Utility of repeated checks for hierarchical classification of data from plant breeding trials. Field Crops Res., 30(12): 79-95. https://doi.org/10.1016/03784290(92)90058-H

De Carvalho, L.P., C.C. Salgado, F.J.C. Farias and V.Q. Carneiro. 2015.Stability and adaptability of cotton genotypes of colorful fibers in relation to the fiber characters. Ciencia Rural, 45(4): 598-606. https://doi.org/10.1590/0103$8478 \mathrm{cr} 2013023$

Dewdar, M.D.H., 2013. Stability analysis and genotype $\mathrm{x}$ environment interactions of some Egyptian cotton cultivars cultivated. Afr. J. Agric. Res. Dep. Agron., Fac. Agric., Fayoum University, Fayoum, Egypt. 8(41): 5156-5160.

Eberhart, S.A. and W.A. Russell. 1966. Stability parameters for comparing varieties. Crop Sci., 6: 36-40. https://doi.org/10.2135/ cropsci1966.0011183X000600010011x

Farias, F.J.C., L.P. De Carvalho, J.L. Da Silva Filho and P.E. Teodoro. 2016. Biplot analysis of phenotypic stability in upland cotton genotypes in Mato Grosso. Genet. Mol. Res., 15(2): gmr 15028009. https://doi.org/10.4238/ gmr.15028009

Iqbal, M.Z., S. Nazir, S.U. Rahman and M. Younas. 2018. Stability analysis of candidate bollgard bt cotton (Gossypium birsutum L.) genotypes for yield traits. Int. J. Biosci. Agric. Biotechnol. Res. Inst., Ayub Agric. Res. Inst. (AARI), Faisalabad Pak., 13(5): 55-63. https://doi.org/10.12692/ ijb/13.5.55-63

Khan, N.G., M. Naveed, N.U. Islam and M.S. Iqbal. 2007. Assessment of new upland cotton genotypes (Gossypium birsutum L.) for yield stability and adaptability. Asian J. Plant
Sci., 6: 1012-1015. https://doi.org/10.3923/ ajps.2007.1012.1015

Killi, F. and E. Harem. 2006. Genotype x environment interaction and stability analysis of cotton yield in Aegean region of Turkey. J. Environ. Boil., 37(2): 427-430.

Maleia, M.P., A. Raimundo, L.D. Moiana, J.O. Teca, F. Chale, E. Jamal, J.N. Dentor and B.A. Adamugy. 2017. Stability and adaptability of cotton (Gossypium birsutum L.) genotypes based on AMMI analysi. Aust. J. Crop Sci., 11(4): 367-372. https://doi.org/10.21475/ ajcs.17.11.04.pne60

Maleia, M.P., P.S. Vidigal-Filho, M.V. Kvitschal and M.G.C. Gonçalves-Vidigal. 2010. Stability and adaptability of commercial cotton cultivars (Gossypium birsutum L. race latifolium H.) in Mozambique. Afr. J. Agric. Res., 5: 539-550.

Moiana, L.D.M., P.S. Vidigal-Filho, M.S. Gonçalves-Vidigal, G.F. Lacanallo, Z. Galván, L.P.Carvalho,M.P.Maleia and N.Mindo. 2014. Application of mixed models for the assessment genotype and environment interations in cotton (Gossypium birsutum L. race latifolium H.) in Mozambique. Afr. J. Bio-Technol., 13: 19851991. https://doi.org/10.5897/AJB2013.12926

Naveed, M., N. Mukhtar, J. Farooq, M. Ilyas and N.U. Islam. 2006. Evaluation of some new strains of Gossypium birsutum L. for yield stability across environments. Environments, 2(1): 17-19.

Pretorius, M.M., J. Allemann and M.F. Smith. 2015. Use of the AMMI model to analyse cultivar-environment interaction in cotton under irrigation in South Africa. Afr. J. Agric., 2: 76-80.

Riaz, M., M. Naveed, J. Farooq, A. Farooq, A. Mahmood, C.M. Rafiq, M. Nadeem and A. Sadiq. 2013. AMMI analysis for stability, adaptability and GE interaction studies in cotton (Gossypium hirsutum L.). J. Anim. Plant Sci., 23(3): 865-871.

Sial, M.A., M.A. Arain and M. Ahmad. 2000. Genotype $\mathrm{x}$ environment interaction on bread wheat grown over multiple sites and years in Pakistan. Pak. J. Bot., 32(1): 85-92.

Steel, R.G.D., J.H. Torrie and D.A. Dickey. 1997. Principles and procedures of statistics: A biometrical approach. New York: McGraw Hill Book Co. Inc, pp. 400-428.

Tuteja, O.P., S. Mahendar and S.K. Verma. 2006. 
Stability analysis for seed cotton yield and its component traits in intraspecific hybrids of Gossypium birsutum L. J. Cotton Res. Dev., 20(2): 171-173. 